\title{
Louise Erdrich's Place in American Literature: Narrative Innovation in Love Medicine
}

\section{Richard Stock}

As a novelist, Louise Erdrich is unique in receiving both popular and critical acclaim. Strangely, her popular appeal has discouraged study of her novels as experimental narrative texts. This is unfortunate, since innovations in Erdrich's novels rival much "experimental" contemporary American fiction. This study outlines a convention of a three-level hierarchy of characters in novels and compares this convention with two experimental American novels: Infinite Jest (1996) by David Foster Wallace and Gravity's Rainbow (1973) by Thomas Pynchon. The study then addresses Erdrich's first novel, Love Medicine (1984), to show that it is unique in not having a main character. Although the other two experimental novels try to do without a main character, neither of them succeed at getting beyond this convention. Love Medicine innovates in at least one major narrative convention in a way that other experimental novels cannot do. This is one way in which Louise Erdrich and Love Medicine compare favorably to some of the most respected experimental contemporary American novels. Erdrich's novels should take their place alongside other experimental American novels, being studied in similar ways, regardless of whether they are also read by a broad public audience.

\section{Keywords}

Louise Erdrich; Narrative; American Literature; David Foster Wallace; Thomas Pynchon; Native American Literature; Love Medicine

\section{Introduction}

Louise Erdrich is a unique figure in contemporary American literature, and especially in contemporary Native American literature, in that her writing has met with both critical and popular success. Alan Chavkin finds her popular success more surprising than her critical success: 
It is perhaps surprising that [Louise Erdrich's] novels have sold impressively in Europe and the United States, because these books, with their multiple narrators, poetic language, experimental structures, and intricate blending of myth and realism, can be difficult. In fact, her departure from conventional realism and her deliberate artifice occasionally remind one of the abstruse metafiction of some postmodernist writers. (2)

Erdrich's place as a postmodern experimental writer seems easy to prove and her popularity is obvious from sales figures. This is no mean feat today, as we package works into categories that can be more easily sold, and writers are strongly encouraged to reproduce the same types of texts that have sold well before. Erdrich manages not only to cross the popular/literary divide, but also genre divides in publishing successful novels, poems, and children's books. This crossing of borders might be less unusual in Native American literature, which explicitly struggles with issues of being "mixed". In any case, Erdrich's reception is generally interesting, but also is a useful topic for analysis. What is it about Erdrich's fiction, especially, that has had this appeal?

I would like to hold that question aloft while I tuck underneath it a question that is perhaps even more difficult. Erdrich has published several novels that form a series centering on several families residing on an American Indian reservation around Matchimanito Lake. These novels are clearly related, containing at least some of the same characters and being set in or near the same locations. The novels range across different times, but often different generations of the same families are featured. This series starts with Love Medicine, Erdrich's first novel, which already was met with both popular and critical success. Love Medicine commands the largest amount of scholarly attention of the Matchimanito novels (Wong 4).

I believe that Erdrich's commercial and popular success has discouraged scholars from asking important questions about the craft of her narrative. We spend time arguing about how and why James Joyce's Ulysses makes sense as a story to a large extent because on a first reading it is completely confusing. With Love Medicine, the reader can have the same kinds of questions about how the text functions as a story, but because Erdrich is able to provide a satisfying casual read while also being innovative, we do not question how or why it is a story. We just assume that the casual reader has provided the best test case possible. But it is also possible that Erdrich has done something that books like Ulysses are not able to do, to defy the convention of story structure while still pleasing a reader who usually relies heavily on that convention. 


\section{Hierarchy of characters in a novel}

In this section I propose that the conventional novel usually includes three levels of character: the main character, a few secondary characters, and potentially very many third-level characters. I then contrast that convention to Love Medicine. To set up that argument, I first address briefly what we call a "story" and the need to focus on "character" in analyzing stories.

A story is usually defined as a narration of events happening over a period of time, and it is important that those events are somehow connected to form a meaningful whole. Sometimes there is a debate about "story" versus "plot". Those who argue for the importance of plot insist that plot requires a meaningful connection among events in the narration, so that story by itself can theoretically be a collection of events without any meaningful connection. Peter Brooks is one example of someone who stresses the importance of the concept of plot. Very early in Reading for the Plot (1984), Brooks states: "[I]f it may be an impossibly speculative task to say what narrative itself is, it may be useful and valuable to think about the kinds of ordering it uses and creates, about the figures of design it makes. Here, I think, we can find our most useful object of attention in what has for centuries gone by the name of plot" (4). However, others find the concept of plot somewhat useless, since it is difficult to come up with examples of stories that do not have meaningful connections among the events narrated. Such an example seems impossible, since it would also require that readers make no connection among events in a story. Shlomith Rimmon-Kenan, in Narrative Fiction: Contemporary Poetics (1983) all but ignores plot, even though it is a book that reviews narrative theory and criticism. The only mention Rimmon-Kenan makes of plot in the text is in reference to how E. M. Forster distinguishes "two types of narrative which he called respectively 'story' and 'plot"” (17). Rimmon-Kenan, however, argues that Forster's crucial difference between story and plot - causality - is useless since the reader interprets causality whether it is directly given in the text or not. "But there is nothing to prevent a causally-minded reader from supplementing Forster's first example [story] with the causal link that would make it into an implicit plot" (17). In an endnote attached to her quotation of Forster, Rimmon-Kenan states: "Note that there is no distinction here between the text and the story or plot abstracted from it, with the consequence that story and plot are contrasted as mutually exclusive narrative forms. If I use 'plot' at all - and I am rather wary of a term which has become too vague in ordinary critical usage - I take it to designate one type of story (the type 
which emphasizes causality) rather than a narrative form opposed to the story" (135). That is, for Rimmon-Kenan, in studying narrative, plot as a concept or a term can be ignored.

For analysis it does seem useful to keep in mind that these causal connections can and perhaps should exist, so that we can further debate what those connections are or could be in a text, but the semantic argument about "story" versus "plot" seems less useful in analysis. When I refer to a "story", I refer to something that is also a plot, or a story with a plot. Conventionally, I do not think we make a distinction.

More interesting for me and important for this study is another aspect of the study of stories that is left assumed in debates such as the one about story versus plot. Issues that undergird such debates rely on more basic aspects of narrative. The causality cited by Rimmon-Kenan requires a certain type of character to be present in the narrative. We identify causality, and many other features of narrative, through human-like personas that we call character.

For both curious and obvious reasons, the issue of character in narrative has received little direct attention in the study of narrative. In Reading People, Reading Plots: Character, Progression, and the Interpretation of Narrative (1989), one of the pre-eminent contemporary scholars of narrative, James Phelan, describes that he was foiled in his attempt at writing a book studying character in narrative. This is the beginning of the Preface to that book:

In the beginning, I set out to write a book about character in narrative. It seemed to me that ... the study of character had always gotten too mixed up with discussions of plot or action ... I intended to isolate the element, analyze its nature, and report my findings to a breathlessly waiting critical world. As the title of this book indicates, however, I too have ended by mixing up the study of character with the study of plot - what is here called progression. (ix)

The study that follows is a rather technical categorization of the relation between "progression" and character, heavy in analysis of narrative examples. Phelan's useful self-awareness in the Preface indicates that one problem with focusing on character in studying narrative is that it is implicated into other factors of narrative, and separating it out is to perform undue violence on the subject of study. However, any aspect of narrative is implicated in all the others, and it is not clear why character would be more difficult to study in 
this way as compared with text, author, narrator, reader, style, etc. It seems to me that character as a topic of study hits too close to home: scholars feel that they either need to too-carefully contextualize any study or, at the other extreme, make implicit assumptions about what character is and does in narrative without reflection.

In Phelan's Preface, he might as well have referred to a study 11 years younger by Seymour Chatman, Story and Discourse: Narrative Structure in Fiction and Film (1978), for Chatman states clearly "[i]t is remarkable how little has been said about the theory of character in literary history and criticism" (107). Chatman's book is a more general study of narrative, so while he addresses character in the study, he does not fill the gap in the research that he identifies. However, he does usefully indicate another possible reason for the ignorance of character: we equate characters with people, and we presume that we know what people are like (being people).

That characters are indeed simply "people" captured somehow between the covers of books or by actors on stage and screen seems an unspoken axiom ... Perhaps the axiom is inevitable, but no one has argued the need to decide if it is, if "character" and "people" are, as Kenneth Burke would say, "consubstantial". Obviously narrative theory should at least contemplate the relationship. And whether we apply to characters the laws of the psychology of personality should be something we do consciously, not merely because we have not thought of alternatives. (108)

Here Chatman not only indicates one reason why critics tend to overlook character, but also scolds the field for doing so, for such a lack of critical attention is unacceptable in modern scholarship. Chatman claims that the only tool developed to critically study character is the concept of a character "trait", which is all too close to how we think about human beings. His main purpose in this section of his book is to show that "traits" are not reducible to "events", or that character is not accurately neglected as subordinate to plot or story. But exactly how to deal with character is beyond the scope of Chatman's study, which ultimately claims that "narrative theory cannot neglect" character (145).

In this study, it is also not my purpose to develop that theory of character, although I believe that it is still lacking in scholarship on narrative. But it will serve us well to consider some rather intuitive conclusions of the impact 
characters - in this case the structure of the cast of characters in a novel - has on a story.

Characters must be present in a story for the meaningful connection between events to exist. That is, human-like personas have to be present in the narration for us to call it a story. On the one hand, this is obvious: in human society and psychology, meaning is made and defined by humans. On the other hand, character is a constructed image of a human, and is not "natural" or inevitable in that sense. It seems to me that character is a necessary component of a story that is rarely cited as part of a definition, but it is important to keep in mind for analysis, even if it is impossible to find counter-examples. For example, Franz Kafka's animal stories work because the animals are humanized (or the humans are animalized). There are plenty of stories with human characters that have animal-like characteristics, but still as a basis readers consider them human or human-like. This flexibility is not surprising given that any character, even the most human-like character imaginable, is still a construction, an imagination of what a human might be like. The field of "unnatural narratology" emphasizes the reality of this construction in storytelling as well as its connection to the human reader (Alber et al.).

The reason why the necessity of character is important to the analysis of stories is to frame debates about how characters are, can, and should be implemented in stories. This is also something that I think is not studied much because it seems obvious. More specifically, I would go further and claim that not only are characters necessary, but the vast majority of our stories have one main character, or protagonist. Again, the difference between these terms seems slight: a "protagonist" connotes a more active moving of the story, but in analysis we could see even a very passive main character as the one who "moves" the story by subtler or structural means. It is hard to imagine a main character who is not also a protagonist.

The search for exceptions to this rule shows just how rare this is. Richard Powers's Gain attempts to put a corporation at the heart of the story, making that corporation the main character. However, one of Powers's points in the story is the historical development of defining a corporation as an individual, in view of the law, anthropomorphizing the corporation.

Not only do most stories require a protagonist, but most stories also have a rather limited set of important characters around the main character, and in general the characters in a story are arranged in a hierarchical fashion. 
Along with that, different story lines are also arranged hierarchically, usually defining the importance of the characters in those story lines. There may be hundreds of named characters in a story, but most often there is still one main character, up to (say) five secondary characters, and the rest reside at a third level of significance. These characters may or may not narrate the story; if they do narrate (parts of) the story, that does not have a direct impact on whether they are a protagonist or part of the smaller set of significant characters. Although the identity of the narrator becomes an important issue in Erdrich's fiction and Love Medicine, here I put that issue aside and focus rather on the typical character set-up in the tradition of the novel no matter how the story is narrated.

The few secondary characters are important in relation to the main character and his or her story line, which is the main story line of the overall story. The relationship to (or, less often, comparison to) the main character is more important than their own characters. These characters are most often the main character's family, friends, colleagues, antagonists, or those who the main character becomes closely connected to for the events of the story being told. These are characters who are named and defined, who can be "round" characters because enough textual attention is paid to them, and because they can be compared to the main character, who gets the most attention.

Third-level characters could be deleted from the story and not much would change. Or, one could be replaced with a different character fulfilling a similar purpose and the story would remain very similar. These characters might form sub-plots of their own, but these are only of local interest or contribute among many other factors to the overall story. They are "supporting" characters but not necessary characters.

How we understand the story itself and what we learn through the story in a novel is funneled through the set-up of characters in the novel. By this I mean the more obvious types of characters and narrators that we are exposed to in the novel, but also the number of characters and their relative importance in the typical three-level hierarchy laid out above. Most often, we make sense of a story through a strong main character, a protagonist. This single persona is almost universally needed in novels to provide coherence and understanding. This kind of structure seems so prevalent that citing examples of stories that obviously follow this scheme teaches us little. More interesting is to mention examples of stories that seem to try to break these rules, and analyze just how close to these rules they still remain. 


\section{Writing against the character convention}

Here I choose Thomas Pynchon's Gravity's Rainbow and David Foster Wallace's Infinite fest as examples of attempts to get beyond the tradition of the structure of characters in novels laid out above. These novels are almost universally accepted as being in the tradition of "difficult", "experimental" novels of which Ulysses is an earlier example. This makes them good (but not the only) examples to test whether and how much such works deviate from tradition. The critical acceptance of these novels as "experimental" novels will serve my purpose to put Erdrich's fiction in the same category as these novels, and further to show that, even on the "experimental" front, her novels outstrip these more celebrated, "difficult" examples. Neither of these novels fit into social categories such as "women's" or "ethnic" literature, which unfortunately allows them a more direct placement into the "American" literary canon. In other words, the choice of these novels is also to put Love Medicine in the rubric of "American" literature along with the existing definition of "Native American" literature.

In Gravity's Rainbow (1973), Thomas Pynchon tries to create a story that honors the preterite in many different ways. That is, Pynchon flattens out hierarchies as much as possible, or even raises those considered "low" in society to the highest level. Of course, Pynchon attempts to do this also in the structure of the story he tells. There are hundreds of characters in the novel, and on a first reading it is difficult to determine any consistent hierarchy or ordering among the characters. But the novel is also typically simply confusing on a first reading, and encourages (or requires) re-reading. That is, understanding of the novel depends on a deeper reading experience. Study of the novel reveals that the novel actually has one main character: Tyrone Slothrop. The novel is structured around his chronological nine-month odyssey and he is the character who gains the most attention. Also, all of the other characters and events seem to have significance in relation to the Slothrop story: there seems to be no part of the novel that does not directly relate to Slothrop, even parts that do not have him present or that take place before his birth.

One of the longer and more interesting subplots in Gravity's Rainbow involves Oberst Enzian and his "Schwarzkommando". This is a group of Africans transplanted to Germany who are enacting a drawn-out ritual of communal suicide that features chasing (information about) the possible ooooo rocket. Large parts of the novel focus on the personalities in this group 
travelling through war-torn Germany on their quest. Slothrop has a similar obsession with the rocket, and while the Enzian subplot brings in many other points of information, the main function in the story of the novel is to show that Slothrop is not alone in being obsessed with this one mythical rocket. Slothrop's quest to find this rocket (or where it exploded) becomes the main driving feature of his story as the novel progresses.

There are also several characters in Gravity's Rainbow who each have their own subplot in the novel but are united together in their attention to Slothrop as a "subject" of scientific observation. Slothrop, of course, does not have direct knowledge of this observation, or at least he starts out that way and slowly gains knowledge as the novel progresses. Characters such as Roger Mexico, Brigadier General Pudding, Ned Pointsman, Kevin Spectro, and others, are characters in their own right and have many scenes among them that do not involve Slothrop, but for the novel they are all present to show the "other side" to the Slothrop story. In particular, Roger Mexico is not only illustrated as a certain kind of mathematical personality, but also features in love scenes with Jessica Swanlake. These scenes have several purposes in the novel, but among them are to show whether and how love can exist amidst war and to further illustrate, in comparison with Jessica, Roger's ideas about Slothrop. One scene shows Jessica unwilling to believe Roger's logical argument that a bomb is just as likely to fall in the same place twice as falling anywhere else. This serves to deepen Roger's scientific perspective and therefore the conclusions he comes to in observing Slothrop.

In the end, Pynchon has to include one main character and a kind of hierarchy among other characters to tell his story. It does seem that his group of secondary characters is much larger than usual, or that he has no secondary characters and has only Slothrop and third-level characters. So Pynchon is able to stray from the traditional typical novel in this way, but he does not seem to get beyond the need for one main character.

David Foster Wallace's Infinite fest (1996) is a novel that appears to contain two intertwining storylines, each with its own main character. The first centers around the Enfield Tennis Academy and the main character is a prodigal young man at the academy named Hal Incandenza. The second mostly takes place at the Enfield House Drug and Alcohol Recovery House and features Don Gately, recovered addict and current staff member at the halfway house. These two story lines share many themes, the locations are close to each other, and they are contemporary to each other (and the main characters do meet briefly), but it is safe to say that each story line could function as a novel on its own. They 
are not intertwining stories with a character in common at different times of his or her life or some similarly obvious connecting factor.

So in one sense this is simply two stories, two novels, in one book. But still, the novel as a whole is structured around the experiences of Hal. It opens with a short scene narrated by $\mathrm{Hal}$ and then jumps back in time a couple years to then narrate more or less chronologically (including both story lines) up to a time before the opening scene. The opening scene has Hal acting very differently than he does in the rest of the book, so there is clearly some development in Hal's story that is purposefully not narrated. That structure can be one reason to see $\mathrm{Hal}$ as the main character of the book and Gately as a secondary character. Perhaps more important is the fact that at least some of the drama of the Hal story involves whether or not he is addicted to substances, and Gately as a recovering addict who daily interacts with other recovering (and relapsing) addicts serves as an illustration of the danger that Hal faces. The Hal story does not serve any such purpose for the Gately story, suggesting that the Hal story is more prominent.

Infinite fest innovates with many narrative conventions: it has many different and often indeterminable narrators, it is set in the near future, it includes references throughout to endnotes (more than 200 pages of endnotes), etc. However, in terms of character, Infinite fest at best is able to have two main characters instead of one (in a book of 1,100 pages) and more likely one would say that it has one main character and an unconventionally highlighted secondary character. It includes a huge amount of third-level characters as many traditional novels do. Each of the story lines does have its own set of secondary characters, who operate in the way I describe above: there are a limited number of these and they are important only in relation to the main character. Again, this novel, although it is quite obvious about its narrative innovations, does not get far beyond the typical novel structure in terms of a hierarchy of characters.

With this analysis of these two novels I do not mean to suggest that they should innovate with the character structure more. But they do suggest the hold that the character structure has over even those who innovate with the novel form. These two examples indicate that even in some of our most innovative fiction, writers have a hard time innovating deeply with the conventional novel structure of characters in the story. This leads me to believe that we usually depend especially on the concept of a main character or protagonist to be able to call something a story. Without a main character, it seems we have a problem even calling it a story at all. Of course, this is a generalization that 
calls for a book-length study to support properly, and in this study I do not want to pretend it is anything more than a generalization. The two examples above are significant and canonical in their field (and different enough to also suggest a kind of representativeness), but they are only two examples among many possible other examples.

But given the canonicity and potential representativeness of these two examples, it is interesting to compare them with such a popular (and critically acclaimed) as well as "ethnic" and/or "women's" work of fiction. On the surface, it seems that Love Medicine does not have a main character, and in this it is similar to the other two novels. One would expect that, since it is more popular, a reliance on a conventional concept of a protagonist would be present. In the next section, however, I show that no such main character exists in Love Medicine, even if one looks closer.

\section{Character in Love Medicine}

To the best of my knowledge, there are no studies available that consider in a detailed way who might be the protagonist of Love Medicine. Most of the critics who address the question at all state that June is the main character, with little support for that claim (below I address some of those claims). William J. Scheick claims that "Love Medicine (and other related novels) lack a conventional structure comprised of a beginning, middle, and end. And instead of decidedly central protagonists, these works present many characters whose memories and identities are as loosely connected as are the stories in which they appear" (117). Scheick, however, offers no analysis to support this claim. In this section my purpose is to provide such an analysis. The best way to gauge whether Love Medicine has a protagonist or not seems to be to consider each of the possible characters in turn.

June Kashpaw seems to be the most likely suspect. Some studies briefly state that June is the main character of the book as if it was obvious. Below I address some of these studies to expose their unsupported conclusion. I know of no studies, in fact, that mention a main character in Love Medicine that does not claim that June is the main character. The first part of the first chapter focuses on June and takes place in 1981. Moreover, this part narrates the strange way that June dies. Because it narrates her death, the narration is in third person, which contrasts with much of the novel. Most of the scene seems to narrate a not-unusual sequence of events in one night of June's life: 
she waits for a bus, gets picked up by a guy in a bar, and has sex with him in his car. But the scene ends with June extracting herself from the car (and from under the sleeping man) and walking to her death by exposure in the extraordinary Easter-weekend snowstorm. This beginning seems to set up June as a main character, and in chapter 2 the narration jumps back to a time in the past, further leading us to believe that we would then get some backstory leading up to June's inexplicable death.

In fact, overall, the story takes place from 1934 to 1984 , and except for analepses and prolepses, the rest of the novel is arranged chronologically, except for the first, June-focused, chapter. This adds yet more weight to the importance of June to the novel as a whole. The first chapter, which focuses on June, is the only one out of chronological sequence. Also, at first glance, it seems that much of the story time of the novel (1934 to 1981) takes place before June's death, when she can indeed exist as a vital character, and only three years (1981 to 1984) that could be a denouement after her death. Peter G. Beidler and Gay Barton's useful "Chronology of Events in Love Medicine" cites events in 32 years spanning from 1898 to 1984 (18-21). Only the first four events take place before 1934, which is the earliest date stamped on a chapter, and these four events are analepses told within an earlier period. Two of them are only references to when characters were born. Therefore, it is not incorrect to say that the story takes place in the years noted on the chapters in the book: 1934 to 1984 .

Indeed, the rest of Chapter 1, which occurs in 1981 after June's death, still focuses on June. The rest of Chapter 1 is narrated by Albertine Johnson, June's niece, and the main topic is Albertine coming back home to the reservation and experiencing her mother and other people talking about June after she died.

Further, the novel ends with the specter of June hanging over Lipsha Morrissey (her son) and Gerry Nanapush (Lipsha's father). With Gerry in attendance, Lipsha wins a car when gambling with June's illegitimate other son, King. King bought the car with the money he got from June's life insurance. Gerry is in attendance, and as Lipsha and Gerry leave in the car, the feeling is that by gaining the car (a red convertible), Lipsha has righted a wrong committed against June. Lipsha drops off Gerry and stands on a bridge looking over the land. The book then ends with this: "I got inside. The morning was clear. A good road led on. So there was nothing to do but cross the water, and bring her home" (367). The "her" in the last sentence is ambiguous as to whether it is June, the car, the car as representative of June, 
or something else. But in any case the novel also ends with June and the same kind of "coming home" theme that occurs in the first chapter with Albertine's narration, just after June died.

However, in the bulk of the book that happens before 1981, June is not treated as a main character. There are 18 chapters in the 1993 version of Love Medicine $^{1}$. 10 of them take place before June's death (chapters 2 to 12). June is a character in just one of these chapters, chapter 5 , and otherwise mentioned only in passing in Chapter 11. In Chapter 11, Albertine Johnson explains her interest in Gerry Nanapush partly because he was "some kind of boyfriend to Aunt June" (195).

The fifth chapter, "The Beads", is set in 1948 and is narrated by Marie Kashpaw, who is June's aunt and who unwillingly takes June into her house as a child but then falls into a deep and fierce love for the child. This is shown most clearly in Marie's reaction when she catches the children playing at hanging June. But half of the chapter continues to narrate other events in Marie's life, and the subject of the first part seems more to be about how and why Marie would take yet another child into her crowded home and establish her bond with June. Nothing particularly interesting or unique about June's character is established here.

This goes against the expectations described above, where you have a first chapter that narrates the strange death of a character and then proceeds to illustrate how other characters related to her discuss her after her death and further that the narration goes back in time, roughly to around when June was born and spends the next 10 of the remaining 17 chapters before the year of her death. But still, June could be an important character after her death in the remaining chapters, even a main character or protagonist. Indeed, compared to the above review of the story time before her death, she does have a larger presence after 1981 in the story.

"Crown of Thorns", the $12^{\text {th }}$ chapter in the novel, is the first chapter after Chapter 1 that takes place after June's death, but just after, still in 1981. It focuses on Gordie, June's husband and cousin. Gordie's reaction to June's death is to drink excessively, and he ends up convincing himself that a deer he hit with his car is June, and he has killed her. June is important to this chapter, but again nothing further of her character is shown except that her death causes her estranged husband to react in a self-destructive manner. This is much more important to understanding the character of Gordie than understanding June.

The next chapter has Lipsha Morrissey, something of a medicine man, 
talking to a ghost as he tells the ghost to go back to the world of the dead. That section ends with "Look up Aunt June,' I whispered as he left" (256). Why Lipsha would choose June as the one that he would want a ghost to get in touch with is not too clear, although it is clear that the ghost itself is not June. However, by the end we find out that June is Lipsha's mother, so this choice has again more to do with Lipsha than June.

Chapter 14 returns to Gordie and in a way picks up where Chapter 12 left off. Gordie, still binge-drinking, has come to his mother, Marie, to get alcohol. The scenes that follow between Gordie and Marie are a combination of family love and the threat of violence. June is naturally included here again as a presence because of Gordie and Marie. To clarify, June and Gordie were both raised as children by Marie in the same household along with the fact that June and Gordie are blood cousins and also married. The middle of the chapter turns to a scene with just June and Gordie, at some time in the past in their life as a couple. Here June gets Gordie to go with her on a spontaneous road trip, staying at an out-of-business lake resort. For the first time since the first part of the first chapter, we get a scene that features June, for six pages, in a flashback.

Chapter 18, the last chapter of the book, frames the novel by bringing June's death to the front of the narrative. However, it is more the consequences of her death that are featured here, and the people who are linked through her and how they are affected, three years after her death, in 1984. Most of the chapter focuses on Lipsha Morrissey again, and is narrated by Lipsha. In this chapter, Lipsha comes to terms with the fact that June is his mother, but more importantly, he learns who his father is, and spends significant time with him. Gerry (Lipsha's father) and Lipsha talk about June, but they do not explicitly discuss that June is Lipsha's mother, although both know it. The scenes are more about the father-son relationship than June herself. The chapter also shows June's other son, King, getting his just desserts for squandering the insurance money he got from June's death on a red convertible.

It seems significant that June died a strange, inexplicable death that has a strong effect on the people related to her. However, Henry Lamartine, Jr. also dies an inexplicable death (moreover, by drowning, which has deep cultural significance). The impact of his death on other characters is perhaps less than June's, but we get at least two versions of how he died and his death is referred to more than once in the story.

Other than the way she dies, the other seemingly significant aspect of June's character is that the novel itself seems to be structured with reference to June. 
It starts with her dying and ends with her son coming to terms with her death and motherhood, setting a positive course as the novel ends. This by itself cannot be a basis on which to determine a main character, although given the review above it is an open question why Erdrich chooses to structure her story around June's death in this way. The most obvious explanation may or may not be correct: that Erdrich simply uses this charged event to structure the novel to add drama to the story overall and to give some basis for a structure to the novel other than simple chronology.

While the novel does start and end with June, so much of the rest of the novel is tangentially about June at best, that June cannot be the protagonist. She becomes more present in the novel in the sections that occur after her death, and this presence is used more to illustrate the alive characters than June herself. This is not surprising, since the dead character would more likely not be developed in such parts of the story. These parts of the novel do not even seek to define or describe June's character through her impact on other characters, either. In the end, June is not a well-defined character in the novel. She is a type: a pretty, independent Native American woman not afraid to gain the pleasures (and suffer the pain) of partying and sleeping around. She is a rather irresponsible mother, and much of her mystique is tied to the freedoms she allows herself, and these freedoms have different impacts on men and women. The reader does not get much more substance on June as a character or person. In addition, while many other characters narrate sections of the novel, and the group of narrators seems to form the second level of significant characters in this novel, June is never a narrator. This can equally be used as evidence to say that she is a main character or that she is a third-level character, which means that it cannot be used as strong evidence either way. Some critics have come to the conclusion that June is paramount to a main character just because she seems to provide the best possibility of a thread that we can use to connect the other various characters and events. Of course, such an effort is deeply informed by the need to find that thread at all in the story contained in a novel, which is not necessarily appropriate.

For example, Kathleen M. Sands claims that "[i]t is June who allows us to penetrate the chaotic and often contradictory world of the Kashpaw and Lamartine families and to bring a sense of history and order to the story, to bring art out of anecdote and gossip" (17). However, the only support Sands offers is what I mention above, that June seems integral to the structure of the novel: the way the novel begins and ends, and the way chapters are organized within the novel. I claim that this, by itself, is not enough to grant 
such prominence to June's character. Alan Chavkin calls June a "haunting presence" and that the "reverberations of her life throughout the book serve as another unifying device" (86). This seems more accurate to me, that she is a unique character, even a unique character in the structure of the narration of the story, but she is not a main character or protagonist.

June is the best candidate for being the main character of Love Medicine. Other characters can now be addressed more briefly, although it is important to consider them as well. The novel often uses a first-person narrator, but not exclusively. There are six different characters who narrate different parts of the novel. First-person narrators are natural candidates for the main character, since devoting narration to the character inevitably places that character on a higher level of influence in the story. All of the first-person narrators in Love Medicine are also characters in chapters where they are not narrators.

Lyman Lamartine narrates two chapters. The purpose of "The Red Convertible" is to describe when Lyman's brother, Henry, drowns in the river. Lyman was the only other person there when it happened, although then the story is told from a different perspective later and Lyman's account comes into question. The other chapter he narrates, "The Tomahawk Factory", departs somewhat from the rest of the story of the novel. In fact, in the 2009 version of the novel, Erdrich chooses to extract this chapter from the novel proper, putting it in an additional section that contains contexts and background information for considering the novel. In other chapters, Lyman is never a focus of the narration, and seems to be more important for things that happen to him rather than his character himself. In addition to being the only witness to Henry's death, he is saved from a burning house by Lulu Nanapush, which again says more about Lulu than Lyman. Lyman is not the main character.

Lulu Nanapush is also the first-person narrator of two chapters. The first, "The Island", tells of Lulu's decision when she was young to move to an island in Matchimanito Lake where Moses Pillager, an outcast and perhaps a witch, lived. Lulu's purpose was to marry Moses and indeed they have children together. This was a scandal both because of Moses's extraordinary nature and that he and Lulu were too closely related. This chapter seems to illustrate that such transgressions did occur and to show Lulu as a free spirit in comparison with other women on the reservation. "The Good Tears" further shows how Lulu was a unique character in marrying two other men after Moses and having children with yet two more, and how she used those secret relations as power over others, especially other women. In the end, though, this chapter is more 
about one of her lovers, Nector Kashpaw, who has a more important role in the story as a whole. Lulu is an interesting minor character, but certainly not the main character.

Nector Kashpaw also only narrates two chapters, but his presence is larger in the book. Lulu Nanapush is his first love, but in an inexplicable scene that he narrates in "Wild Geese", he becomes infatuated with Marie Lazarre and eventually marries her, has five children with her, and also takes other children in need of shelter into their household. This is the household in which June and Gordie grew up. In other chapters mostly narrated by Marie, we see Nector rise in local reservation politics until he is chair of the tribe. His success is apparently the work of Marie, behind the scenes. But in "The Plunge of the Brave" Nector shows his bewilderment at his success and his continuing weakness for Lulu, with whom he has a son, secretly. Nector tries to leave Marie for Lulu, and in his confusion in trying to abandon his home and move in with Lulu, he burns Lulu's house down, which is when Lulu saves her child Lyman from the fire. Nector is important to this part of the story involving these characters and events, but there are large parts of the novel where he is irrelevant. Although he was a father figure to June, her story seems little affected by him. The narratives surrounding Gerry Nanapush, Albertine Johnson, and even Lulu's early life are not affected by Nector. Even much of Lipsha Morrissey's story, which includes more or less causing Nector's death, is not closely linked to Nector. Moreover, while the part of the novel that does feature Nector is perhaps longer and more significant than that of Lulu or Lyman, the novel as a whole has no structural relation to his character like it does for June, for example. Nector also does not seem to be a main character.

Albertine Johnson narrates the remainder of the first chapter that does not narrate June's death, and those sections serve to illustrate that June's death is recognized and talked about on the reservation, which I mention above. Albertine then narrates a chapter about a relationship between Dot Adare and Gerry Nanapush, and Albertine seems to be the happenstance witness to their romance because of her job with Dot. She is not a main character.

Marie Kashpaw also narrates two chapters, and as Nector's wife and the one responsible for the large household of children they raised, she has an influence that spreads wide across the novel. Her two chapters, "Saint Marie" and "Flesh and Blood", mainly narrate Marie's experience living in the convent as a young woman and then returning to confront Sister Leopolda later in life with her daughter, Zelda. The convent experience serves as a basis to illustrate 
Marie's interesting combination of love and hate for all things: religion, herself, authority, her husband, her children, and her community. The end of "Flesh and Blood" has Marie accepting Nector back into their home after he tried to leave her for Lulu, when he comes back after burning down Lulu's house. That act is not clearly love or hate, or something else like calculation. In the end, however, Marie's position in the novel is like Nector's. She is prominent in some parts and has an effect on many characters through those she raises and marries, but other parts of the novel are almost completely divorced from her character. This makes her not a candidate for the main character of the novel.

Lipsha Morrissey is the last character that has first-person narration and as the novel progresses he indeed becomes more and more important to the story. He narrates the eponymous "Love Medicine" chapter referred to above, that tells how Lipsha always had a special "touch" to heal others and how he tries to use that touch to get Marie and Nector back together in their old age. His "love medicine" goes awry, however, when Nector chokes to death on it. Lipsha's lineage is potentially important, since he is the son of June and Gerry Nanapush. Gerry is a mythic figure throughout the book: an outlaw Indian who is continually being put in prison and escaping from prison for a crime that it seems he did not commit, or that was justified. Gerry seems to be a fictionalized version of the real-life Leonard Peltier, who is also a mythic figure that American Indian activists have rallied around. Plus, Lipsha is raised by Nector and Marie, although as June's son, he is a generation older than others who had been raised in that household (and consequently he calls Nector and Marie Grandpa and Grandma). Lipsha then narrates the significant end of the novel, where he, along with Gerry, seem to correct some wrongs that June's other son, King, has committed since June's death, and in a coded way Gerry and Lipsha share their family connection. Lipsha is a unique and interesting character in himself, and is active in making some things happen in the story, but in the end much of his importance relies on the importance of others in the novel: Marie, Nector, June, Gerry. He is not a protagonist in this sense.

This group of first-person narrators approximates the "second tier" of characters that I describe above (perhaps with the addition of Gerry Nanapush and perhaps not including Albertine Johnson). Along with June, that makes four to seven characters who seem important but none of whom is the main character, each for a different reason. The fact is that there is no one main character in Love Medicine. 


\section{Conclusion}

Even novels that we celebrate as "experimental" often still rely on the convention of having one main character that provides the main thread of a novel's otherwise potentially complicated and multivalent story. Gravity's Rainbow was able to innovate with typical novel character structure by expanding the cast of secondary characters, or perhaps doing away with secondary characters altogether. But Gravity's Rainbow is not able to free itself from the more basic convention of a clear main character. Infinite fest departs from the conventional way that characters are arranged in a novel by combining two novels into one, or making one secondary character more emphasized than other secondary characters, with his own group of defining characters. Perhaps Infinite fest is able to create a mid-level, or sub-level, within the secondary characters. But again, Infinite fest is not able to do away with the conventional main character. Love Medicine, however, creates a coherent story without a main character. The novel still has a group of secondary characters, but a relatively small group of third-level characters.

The anecdotal comparison of Love Medicine with Gravity's Rainbow and Infinite fest shows that the narrative structure of Love Medicine is able to innovate at least as deeply, and probably on a deeper level, than these other novels that are more often depicted as "experimental" and worthy of narrative study. Moreover, Love Medicine is able to do this while still remaining appealing to a more casual reader. Appealing to a large audience is not necessarily a worthwhile goal in creating literature, and it is not clear that Erdrich herself had this in mind when producing Love Medicine. But I see it as a certain unique achievement that Erdrich is able to do what we usually assume is not possible: please both the critics and the general reader, and both of these now over a period of 30 years.

\section{Notes}

1. Love Medicine has been published in three versions to date. The first version was published in 1984. Love Medicine: New and Expanded Version was published in 1993, and included many significant changes. Critics debate which of these two versions should be used for study, but for my purposes the later version is more appropriate. In 2009, Erdrich published a third version on the $25^{\text {th }}$ anniversary of the original publication, making some minor changes and moving one chapter from the main text to a "Notes" section at the end of the book (which also includes an author interview and other such resources). 


\section{Works Cited}

Alber, Jan, Stefan Iversen, Henrik Skov Nielsen, and Brian Richardson. "Unnatural Narratives, Unnatural Narratology: Beyond Mimetic Models." Narrative 18, no. 2 (May 2010): 113-136. Print.

Alber, Jan. "Impossible Storyworlds-and What to Do with Them." StoryWorlds: A fournal of Narrative Studies 1 (2009): 79-96. Print.

Beidler, Peter G. and Gay Barton. A Reader's Guide to the Novels of Louise Erdrich: Revised and Expanded Edition. Columbia: University of Missouri Press, 2006. Print.

Brooks, Peter. Reading for the Plot: Design and Intention in Narrative. Cambridge: Harvard University Press, 1984. Print.

Chatman, Seymour. Story and Discourse: Narrative Structure in Fiction and Film.

Ithaca: Cornell University Press, 1978. Print.

Chavkin, Allan. "Introduction." The Chippewa Landscape of Louise Erdrich, 1-7.

Ed. Allan Chavkin. Tuscaloosa: The University of Alabama Press, 1999. Print.

---. "Vision and Revision in Louise Erdrich's Love Medicine." The Chippewa Landscape of Louise Erdrich, 84-116. Ed. Allan Chavkin. Tuscaloosa: The University of Alabama Press, 1999. Print.

Erdrich, Louise. Love Medicine. New York: Holt, Rinehart and Winston, 1984. Print.

---. Love Medicine: Neroly Revised Edition. New York: Henry Holt and Company, Inc., 20og. Print.

---. Love Medicine: New and Expanded Version. New York: HarperCollins Publishers, Inc., 1993. Print.

Joyce, James. Ulysses. 1922. New York: Vintage Books, 1986. Print.

Phelan, James. Reading People, Reading Plots: Character, Progression, and the Interpretation of Narrative. Chicago: University of Chicago Press, 1989. Print.

Powers, Richard. Gain. New York: Farrar, Straus and Giroux, 1998. Print.

Pynchon, Thomas. Gravity's Rainbow. New York: Penguin Books, 1973. Print.

Rimmon-Kenan, Shlomith. Narrative Fiction: Contemporary Poetics. London: Routledge, 1983. Print.

Sands, Kathleen M. "Love Medicine: Voices and Margins." Studies in American Indian Literatures 9, no.1 (Winter 1985): 12-24. Print.

Scheick, William J. "Narrative and Ethos in Erdrich's 'A Wedge of Shade." 
In The Chippewa Landscape of Louise Erdrich, 130-143. Ed. Allan Chavkin. Tuscaloosa: The University of Alabama Press, 1999. Print. Wallace, David Foster. Infinite fest. New York: Back Bay Books, 1996. Print. Wong, Hertha D. Sweet. "Introduction." Louise Erdrich's Love Medicine: A Casebook, 3-10. Ed. Hertha D. Sweet Wong. New York: Oxford University Press, 2000. Print.

RICHARD T. STOCK is currently an Assistant Professor in the English Studies Department at the Faculty of Philosophy at the University of South Bohemia in České Budějovice. His research interests include contemporary and postmodern American literature, the novel and novel theory, narrative and narrative theory, and Native American (American Indian) literature. $\mathrm{He}$ is originally from the U.S. and has academic degrees from the University of Illinois at Urbana-Champaign, U.S.A., the University of Reading, UK, and Charles University in Prague.

rstock@ff.jcu.cz 